\title{
Citing Behavior of Korean Scientists on Foreign Journals in KSCD
}

\author{
$\mathrm{KSCD}$ 를 활용한 국내 과학기술자의 해외 학술지 인용행태 연구 \\ Byung-Kyu Kim*, MuYeong Kang**,
Soon-Young Kim****, Beom-Jong You*****, Jeoni Choi*** \\ ABSTRACT
}

\begin{abstract}
There have been little comprehensive research for studying impact of foreign journals on Korean scientists. The main reason for this is because there was no extensive citation index database of domestic journals for analysis. Korea Institute of Science and Technology Information (KISTI) built the Korea Science Citation Database (KSCD), and have provided Korea Science Citation Index (KSCI) and Korea Journal Citation Reports (K.JCR) services. In this article, citing behavior of Korean scientists on foreign journals was examined by using KSCD that covers Korean core journals. This research covers (1) analysis of foreign document types cited, (2) analysis of citation counts of foreign journals by subject and the ratio of citing different disciplines, (3) analysis of language and country of foreign documents cited, (4) analysis of publishers of journals and whether or not journals are listed on global citation index services and (5) analysis for current situation of subscribing to foreign electronic journals in Korea. The results of this research would be useful for establishing strategies for licensing foreign electronic journals and for information services. From this research, immediacy citation rate (average 1.46\%), peak-time (average 3.9 years) and half-life (average 8 years) of cited foreign journals were identified. It was also found that Korean scientistis tend to cite journals covered in SCI(E) or SCOPUS, and $90 \%$ of cited foreign journals have been licensed by institutions in Korea.
\end{abstract}

\section{초 록}

국내 과학기술전반에 걸쳐 주제분야별로 해외 학술지 인용비율 즉 해외 학술지 영향력에 대한 종합적인 분석은 부족한 실정이며 가장 큰 원인은 종합 분석이 가능한 국내 학술지에 대한 대규모 인용색인 데이터베이스의 부재였다. KISTI는 한국 과학기술 인용색인 데이터베이스인 $\mathrm{KSCD}$ 를 구축하고 한국과학기술인용색인서비스 $(\mathrm{KSCI})$ 를 제공하고 있다. 본 논문에서는 국내 과학기술분야 핵심 학술지를 포괄하는 $\mathrm{KSCD}$ 를 활용하여 국내 과학기술분야 연구자들의 해외 학술지 인용행태에 대한 분석 연구를 수행하였다. 연구 범위는 첫째, 해외 인용문헌의 형태별 분석을 둘째, 해외 학술지 인용문헌의 주제별 피인용수 및 타분야 인용비율 분석을, 셋째, 해외 학술지 인용문헌의 언어 및 발행국가 분석을, 넷째, 해외 학술지 발행기관 및 글로벌 인용색인 서비스 등재현황 분석을 마지막으로 국내의 해외 전자저널 구독 현황 분석이다. 해외학술지 인용분석을 통한 연구의 주요성과로는 해외 인용 학술지의 인용절정기(평균 3.9 년), 반감기(평균 9 년)의 규명과 한국 연구자들이 주로 해외등재학술지를 인용하며 국내에서 인용 해외등재학술지의 $90 \%$ 정도가 전자저널로 구독되고 있음을 밝힌 점이다. 본 연구를 통한 국내 과학자들의 해외 학술지 인용행태 분석 결과는 해외 전자저널 구독 전략 수립에 도움이 될 수 있을 것으로 기대된다.

Keywords: citation analysis, behavior of citing the foreign journal, half-life, KSCD, KSCI, KJCR 인용분석, 해외저널 인용행태, 반감기, $\mathrm{KSCD}, \mathrm{KSCI}, \mathrm{KJCR}$

* Korea Institute of Science and Technology Information, Dept. of Knowledge Resources Knowledge Information Center, Senior Researcher(yourovin@kisti.re.kr)

** Korea Institute of Science and Technology Information, Dept. of Knowledge Resources Knowledge Information Center, Principal Researcher(kmy@kisti.re.kr)

*** Korea Institute of Science and Technology Information, Dept. of Knowledge Resources Knowledge Information Center, Senior Researcher(sunny.choi@kisti.re.kr)

**** Korea Institute of Science and Technology Information, Dept. of Knowledge Resources Knowledge Information Center, Senior Researcher(maya@kisti.re.kr)

***** Korea Institute of Science and Technology Information, Dept. of Knowledge Resources Knowledge Information Center, Director(ybj@kisti.re.kr)

****** Department of Computer Engineering, Chungnam National University(airsin@nate.com)

- Received : 17 May 2011 - Revised : 24 May 2011 - Accepted : 10 June 2011

- Journal of the Korean Society for Information Management, 28(2): 117-133, 2011. 〔DOI:10.3743/KOSIM.2011.28.2.117〕 


\section{Introduction}

\subsection{Research goals and needs}

As the importance of science and technology increases, figuring out the characteristics of resources scientists reference for their research is significant to researchers and information service providers. To understand information use behavior of scientists, analyzing cited documents is an easy and objective method. Citation analysis is a method of analyzing a relationship between cited documents and citing documents in order to examine the usage of journal articles. As a research area of bibliometrics, the objective of citation analysis is to characterize resources cited by information creators (Friss 1955). Even though many studies and experiments have been carried out to measure the value of scientific and technical documents and find evaluation methods for them, the most objective and reasonable method could be citation analysis that applies bibliometric methods to cited references (kim 2002; Bonzi \& Snyder 1991). By analyzing citations quantitatively, it is possible to figure out types, languages, preferences of information used, and the phenomenon of information use (Kim 2003).

Although the research of analyzing citing behavior of Korean scientists showed that Korean scientists have frequently cited foreign journal articles, it is impossible to subscribe to all foreign journals because of consistently increasing subscription fee. This means that it is difficult to satisfy all users needs even though we spend lots of money in purchasing foreign journals. Thus, we need to identify users' information needs and to find an efficient way for meeting users' needs before investing budget in purchasing foreign journals (Ko 2005). However, there have been little comprehensive research for investigating the impact of foreign journals (i.e., ratio of citing foreign journals) by discipline. The objective of this research is to quantify and visualize citing behavior of Korean scientists and to figure out the extent to which they use foreign journals. This will provide basic information for selecting and providing foreign scientific information and assist the acquisition of information by researchers.

\subsection{Research method and scope}

This research utilizes the Korea Science Citation Database (KSCD) and the Korea Journal Citation Reports (KJCR) of the Korea Institute of Science and Technology Information (hereafter: KISTI). KSCD is the database supporting services of Korean scientific information services (i.e., NDSL, KSCI, Korea Society Community of Science and Technology, KoreaScience), which have core journals of Korean science and technology and other scientific information. For this research, 459 kinds of Korean journals in science and technology published from 2005 to 2009 were selected. Specifically, articles and cited references in journals were investigated. Also, the journal database of e-Gate Knowledge Base in KISTI was used in identifying foreign journals and calculating the number of citation counts for those journals. "e-Gate Knowledge Base" is the larg- 
est gateway database in Korea, which has licence information for electronic full-text documents by institutions in KESLI (Korean Electronic Site License Initiative), a consortium of making a group purchase for electronic information. This research covers (1) analysis of foreign document types cited, (2) analysis of citation counts of foreign journals by subject and the ratio of citing different disciplines, (3) analysis of language and country of foreign documents cited, (4) analysis of publishers of journals and whether or not journals are listed on global citation index services and (5) analysis for current situation of subscribing to foreign electronic journals in Korea.

\section{Previous studies}

Using cited references of journal articles to examine a relationship among documents is reliable because authors of journal articles cite articles that were evaluated and were really used in their work. Cited references to journal articles are also proper for applying bibliometric methods, so that it can provide the big picture of information resource usage (Ko 2005). This also enables us to figure out the environment of information use and citing behaviors of researchers without interviewing or surveying user groups.

Citation analysis has been applied to many disciplines (e.g., economics, education, law, science, technology) internationally, just as Gross \& Gross firstly applied it to the discipline of chemistry (Ko 2005). Related research in and outside of the country since 2005 is organized in $<$ Table $1>$ below. Overall, it turned out that many researchers have performed their researches not only for information retrieval or evaluative purposes but also for finding any patterns from citation such as preference of information type, information life cycle, collaborations among researchers, and demands for current information by academic fields or researchers. In particular, research using citation analysis such as networks among researchers, integration among academic fields, developmental process of academic fields or research trends, knowledge map, have been productively performed recently (Cho 2010).

〈Table 1〉 Previous Korean Studies

\begin{tabular}{|c|c|c|c|c|c|}
\hline $\begin{array}{c}\text { Year of } \\
\text { Publication }\end{array}$ & Field & Purpose & Sample & Result & Conclusion \\
\hline $\begin{array}{l}\text { Hyun-Yang Cho, } \\
2005\end{array}$ & $\begin{array}{l}\text { Mechanical, } \\
\text { Architectural, } \\
\text { Electrical and } \\
\text { Electronic } \\
\text { area }\end{array}$ & $\begin{array}{l}\text { Analysis of citing } \\
\text { behavior of } \\
\text { researchers by field }\end{array}$ & $\begin{array}{l}29,610 \text { cited } \\
\text { documents of } 2,333 \\
\text { articles in } 1999,2001, \\
2003\end{array}$ & $\begin{array}{l}\text { - Researchers in electronics } \\
\text { are likely to cite conference } \\
\text { proceedings at a relatively } \\
\text { high percentage (16.54\%) } \\
\text { - Dependency on English } \\
(89 \%) \text { is the highest in } \\
\text { electronics } \\
\text { - The citation half-life of } \\
\text { mechanical engineering and } \\
\text { electronics are } 8 \text { years and } \\
6 \text { years each }\end{array}$ & $\begin{array}{l}\text { - Researchers in engineering } \\
\text { are more likely to cite } \\
\text { articles, followed by books, } \\
\text { proceedings, reports, } \\
\text { dissertations, web } \\
\text { resources, and others. } \\
\text { - Researchers in engineering } \\
\text { rely on current resources. }\end{array}$ \\
\hline
\end{tabular}


120 Journal of the Korean Society for Information Management, 28(2), 2011

\begin{tabular}{|c|c|c|c|c|c|}
\hline $\begin{array}{l}\text { Year of } \\
\text { Publication }\end{array}$ & Field & Purpose & Sample & Result & Conclusion \\
\hline $\begin{array}{l}\text { Seong-Soon Ko, } \\
\text { Sang-Ki Choi, } \\
2005\end{array}$ & \begin{tabular}{|l|} 
Engineering, \\
Natural \\
science, Social \\
Science, \\
Humanities, \\
Arts and \\
Physical \\
Education
\end{tabular} & $\begin{array}{l}\text { To figure out the use } \\
\text { behavior of } \\
\text { professors for } \\
\text { international } \\
\text { journals based on } \\
\text { cited references }\end{array}$ & $\begin{array}{l}\text { Among } 4,749 \text { foreign } \\
\text { articles cited by } \\
\text { Korean } 258 \text { articles } \\
\text { published in Korean } \\
\text { journals from } 2002 \text { to } \\
2003,1,030 \\
\text { (engineering), } 741 \\
\text { (natural science), } \\
2,286 \text { (social } \\
\text { science), 636 } \\
\text { (humane studies), } \\
\text { and 56 (arts and } \\
\text { physical education) } \\
\text { articles were selected }\end{array}$ & $\begin{array}{l}\text { - Journal articles were more } \\
\text { likely to be cited in } \\
\text { engineering, natural science, } \\
\text { and social science } \\
\text { - } 68.2 \% \text { of cited references } \\
\text { was SCI listed } \\
\text { - Journals published in recent } \\
6 \text { to } 10 \text { years were frequently } \\
\text { cited }\end{array}$ & $\begin{array}{l}\text { It is necessary to select } \\
\text { journals that meet users } \\
\text { needs and the goal of library } \\
\text { by using the result of citation } \\
\text { analysis }\end{array}$ \\
\hline $\begin{array}{l}\text { Jong-Yup Han, } \\
2007\end{array}$ & $\begin{array}{l}\text { Marine } \\
\text { Science }\end{array}$ & $\begin{array}{l}\text { To examine the } \\
\text { current condition of } \\
\text { OSJ and to set an } \\
\text { achievable plan }\end{array}$ & $\begin{array}{l}23,096 \text { cited } \\
\text { documents of } 679 \\
\text { articles from } 4 \text { SCI } \\
\text { journals in OSJ and } \\
\text { JCR published from } \\
2005 \text { to } 2007\end{array}$ & $\begin{array}{l}\text { - OSJ takes } 184.8 \text { days in } \\
\text { average (faster than JCR) } \\
\text { - OSJ has } 7 \text { more references } \\
\text { than SCI in average } \\
\text { - Cited SCI journals from OSJ } \\
\text { has } 0.683 \text { bigger impact } \\
\text { factor in average than those } \\
\text { from JCR }\end{array}$ & $\begin{array}{l}\text { - The number of researchers } \\
\text { of an article in four journals } \\
\text { has high percentage of } \\
\text { co-authorship } \\
\text { - OSJ includes relatively } \\
\text { more authors from Asia } \\
\text { - OSJ includes relatively } \\
\text { more authors who work in } \\
\text { research institutes and } \\
\text { universities } \\
\end{array}$ \\
\hline $\begin{array}{l}\text { So-Young Yu, } \\
\text { Jae-Yun Lee, } \\
2008\end{array}$ & Life Sciences & \begin{tabular}{|l|} 
A structural \\
analysis of citation \\
network within an \\
institution in order \\
to find the effect of \\
the citation network \\
on citation patterns \\
of the institution \\
and in deciding the \\
importance of \\
journals in the \\
institution \\
\end{tabular} & $\begin{array}{l}122 \text { articles published } \\
\text { from } 2006 \text { to } 2007 \text { by } \\
\text { professors in } \\
\text { biotechnology }\end{array}$ & $\begin{array}{l}\text { - Biochemical research } \\
\text { including cytology in Y } \\
\text { university has high } \\
\text { productivity } \\
\text { - Citation count for Journal of } \\
\text { Biological Chemistry that } \\
\text { belongs to biochemical field } \\
\text { is } 69 \text {, the highest citation } \\
\text { frequency in the institution }\end{array}$ & $\begin{array}{l}\text { - Analysis of citation } \\
\text { network of the institution } \\
\text { provides useful information } \\
\text { for research trends and } \\
\text { journal citation in the } \\
\text { institution that might not } \\
\text { be acquired by simple } \\
\text { citation counts }\end{array}$ \\
\hline $\begin{array}{l}\text { Seung-Won Lee, } \\
2008\end{array}$ & Chemistry & $\begin{array}{l}\text { To examine } \\
\text { information use } \\
\text { behaviors of users }\end{array}$ & $\begin{array}{l}\text { The total number of } \\
\text { doctoral } \\
\text { dissertations from } \\
2000 \text { to } 2008: 3,258\end{array}$ & $\begin{array}{l}\text { - "Journal of American } \\
\text { Chemical Society" had been } \\
\text { the most highly cited ( } 232 \\
\text { times, } 7.64 \% \text { ) } \\
\text { - Researchers prefer to cite } \\
\text { journal articles }\end{array}$ & $\begin{array}{l}\text { - The most highly cited } \\
\text { document type is journal } \\
\text { articles }(90 \%) \\
\text { - The number of necessary } \\
\text { journals satisfying } 50 \% \text { of } \\
\text { user needs is } 27 \text { types of } \\
\text { journals } \\
\text { - } 50 \% \text { of cited documents } \\
\text { was } 7.6 \text { years old } \\
\text { - Researchers in chemistry } \\
\text { prefer to use journals, and } \\
\text { they tend to rely on } \\
\text { documents written in } \\
\text { English }\end{array}$ \\
\hline
\end{tabular}

Although various citation research have been performed in science and technology in order to figure out citing behavior of researchers, there have been little comprehensive citation research that analyzes citing behavior of researchers on foreign journals in every field of science and technology. In response to this, the research analyzing a vast amount of citations from the whole field of science and technology 
has a value to understand Korean scientists' citing behaviors on foreign journals.

\section{Analysis of Result}

\subsection{Type of cited foreign documents}

The KSCD has over one million scientific journal articles and six million references to those articles. This research analyzed citation data of journal articles published between 2005 and 2009 because using recent five years of data is reliable for statistical analysis in terms of currency and accuracy. Specifically, this research analyzed 459 types of Korean journals in science and technology, which are the foundations for KJCR and KSCI services of KISTI. As mentioned in the introduction, the whole scope of data covers 14,985 foreign journals that could have been identified from the mapping with e-Gate Knowledge Base. And it was found that 14,985 foreign journals were cited about 1.9 million $(1,876,373)$ times. In this paper, citation analysis was done with broad and narrow classifications of subject to show various aspects of the results. The results of analysis were also explained with table and graph. $<$ Table $2>$ shows the scope of analysis and demonstrates the ratio of domestic to foreign citations by subject between 2005 and 2009 .

The result showed that $75.35 \%$ of cited documents is foreign documents (i.e., documents published in the foreign journals), and the ratio of citing foreign documents was different depending on subject as shown in $<$ Table $2>$. The type of foreign documents cited were shown in $<$ Figure $1>$ below, and $78 \%$ of cited foreign documents was journal article.

〈Table 2〉 Ratio of Citing Korean to Foreign Documents in KSCD (2005 2009)

\begin{tabular}{c|l|r|r|r|r}
\hline $\begin{array}{c}\text { Broad } \\
\text { Classification }\end{array}$ & \multicolumn{1}{c|}{$\begin{array}{c}\text { Narrow } \\
\text { Classification }\end{array}$} & $\begin{array}{c}\text { Citing domestic } \\
\text { documents }\end{array}$ & $\begin{array}{c}\text { Citing foreign } \\
\text { documents }\end{array}$ & $\begin{array}{c}\text { Domestic } \\
\text { citation rate }\end{array}$ & $\begin{array}{c}\text { Foreign } \\
\text { citation rate }\end{array}$ \\
\hline \multirow{5}{*}{ Natural Science } & Mathematics & 3,282 & 33,594 & $8.90 \%$ & $91.10 \%$ \\
\cline { 2 - 5 } & Astronomy & 5,712 & 15,227 & $27.28 \%$ & $72.72 \%$ \\
\cline { 2 - 6 } & Physics & 17,250 & 105,802 & $14.02 \%$ & $85.98 \%$ \\
\cline { 2 - 6 } & Chemistry & 15,265 & 93,757 & $14.00 \%$ & $86.00 \%$ \\
\cline { 2 - 6 } & Ethnography, Geology & 19,787 & 44,283 & $30.88 \%$ & $69.12 \%$ \\
\cline { 2 - 6 } & Life Science & 29,356 & 161,480 & $15.38 \%$ & $84.62 \%$ \\
\cline { 2 - 6 } & Plant & 9,332 & 33,122 & $21.98 \%$ & $78.02 \%$ \\
\cline { 2 - 6 } & Animals & 15,817 & 63,608 & $19.91 \%$ & $80.09 \%$ \\
\hline \multirow{5}{*}{ Applied Science } & Computer Information & 13,811 & 72,714 & $15.96 \%$ & $84.04 \%$ \\
\cline { 2 - 6 } & General Technology and Science & 1,112 & 8,138 & $12.02 \%$ & $87.98 \%$ \\
\cline { 2 - 6 } & General Engineering & 29,210 & 119,890 & $19.59 \%$ & $80.41 \%$ \\
\cline { 2 - 6 } & Applied Physics & 31,926 & 166,565 & $16.08 \%$ & $83.92 \%$ \\
\cline { 2 - 6 } & Construction, Architecture and Civil Engineering & 60,236 & 94,530 & $38.92 \%$ & $61.08 \%$ \\
\cline { 2 - 6 } & Urban and Environment & 15,502 & 26,724 & $36.71 \%$ & $63.29 \%$ \\
\cline { 2 - 6 } & Agriculture & 60,130 & 155,005 & $27.95 \%$ & $72.05 \%$ \\
\cline { 2 - 6 } & Home Economics & 93,071 & 63,879 & $59.30 \%$ & $40.70 \%$ \\
\cline { 2 - 6 } & Chemical Engineering & 53,357 & 206,030 & $20.57 \%$ & $79.43 \%$ \\
\cline { 2 - 6 } & Manufacturing & 15,294 & 39,182 & $28.07 \%$ & $71.93 \%$ \\
\hline
\end{tabular}


122 Journal of the Korean Society for Information Management, 28(2), 2011

\begin{tabular}{c|l|r|r|r|r}
\hline $\begin{array}{c}\text { Broad } \\
\text { Classification }\end{array}$ & \multicolumn{1}{c|}{$\begin{array}{c}\text { Narrow } \\
\text { Classification }\end{array}$} & $\begin{array}{c}\text { Citing domestic } \\
\text { documents }\end{array}$ & $\begin{array}{c}\text { Citing foreign } \\
\text { documents }\end{array}$ & $\begin{array}{c}\text { Domestic } \\
\text { citation rate }\end{array}$ & $\begin{array}{c}\text { Foreign } \\
\text { citation rate }\end{array}$ \\
\hline \multirow{5}{*}{$\begin{array}{c}\text { Medicine \& } \\
\text { Pharmacy }\end{array}$} & General Medicine & 17,054 & 89,163 & $16.06 \%$ & $83.94 \%$ \\
\cline { 2 - 6 } & Basic Medical & 9,944 & 58,423 & $14.55 \%$ & $85.45 \%$ \\
\cline { 2 - 6 } & Social Medicine & 41,387 & 78,284 & $34.58 \%$ & $65.42 \%$ \\
\cline { 2 - 6 } & Pharmacology \& Therapeutics & 28,314 & 93,999 & $23.15 \%$ & $76.85 \%$ \\
\cline { 2 - 6 } & Internal Medicine & 43,868 & 221,141 & $16.55 \%$ & $83.45 \%$ \\
\cline { 2 - 6 } & Surgery & 31,776 & 180,111 & $15.00 \%$ & $85.00 \%$ \\
\cline { 2 - 6 } & Obstetrics and Gynecology & 7,089 & 40,100 & $15.02 \%$ & $84.98 \%$ \\
\hline Others & Others & 131,998 & 183,636 & $41.82 \%$ & $58.18 \%$ \\
\hline \multicolumn{2}{c|}{ Total } & 800,880 & $2,448,387$ & $24.65 \%$ & $75.35 \%$ \\
\hline
\end{tabular}

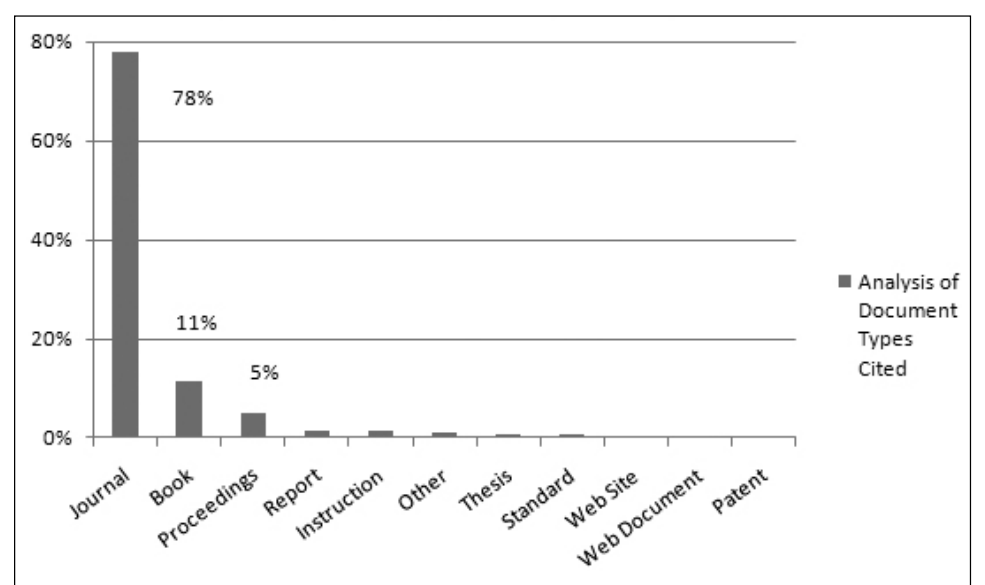

〈Figure 1〉 Citation Ratio by Document Type

\subsection{Citation counts for foreign journals and ratio of citing different discipline}

The number of cited foreign journals and citation counts for each journals were shown in $<$ Table $3>$. Medicine \& pharmacy had the biggest number of cited journals, followed by applied science and natural science. For citation counts, medicine \& pharmacy was the most highly cited, followed by natural science and applied science.

Subject fields were classified more precisely in $<$ Figure $2>$. Overall, there was a positive relationship between the number of cited journals and citation counts. For chemistry, however, citation count was relatively high compared to its number of cited journals. And computer and information had quite low citation count compared with its number of cited journals.

The analysis on ratio of citing different disciplines showed that applied science has the highest ratio of citing other disciplines, followed by natural science and medicine \& pharmacy (Figure 3). Overall, the rate of citation from researchers' own disciplines was higher than that from disciplines outside of researchers' fields. 
〈Table 3〉 Number of Journals and Citation Counts for Each Journals (by Subject)

\begin{tabular}{l|r|r|r|r}
\hline \multicolumn{1}{c|}{ Discipline } & Natural Science & Applied Science & Medicine \& Pharmacy & Total \\
\hline Number of Journal & 4,602 & 4,665 & 5,387 & 14,985 \\
\hline Citation Count & 635,174 & 456,558 & 784,641 & $1,876,373$ \\
\hline Ratio of Journal & $31.4 \%$ & $31.8 \%$ & $36.8 \%$ & $100 \%$ \\
\hline Ratio of Citation Count & $33.9 \%$ & $24.3 \%$ & $41.8 \%$ & $100 \%$ \\
\hline
\end{tabular}

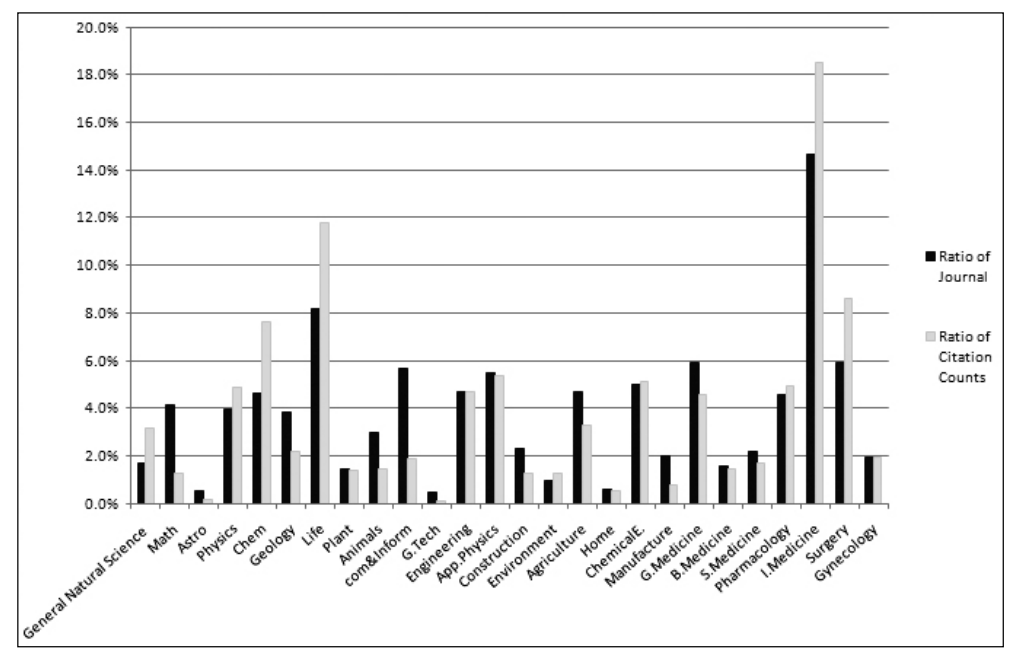

〈Figure 2〉 Comparison for Ratio of Journals and Citation Counts

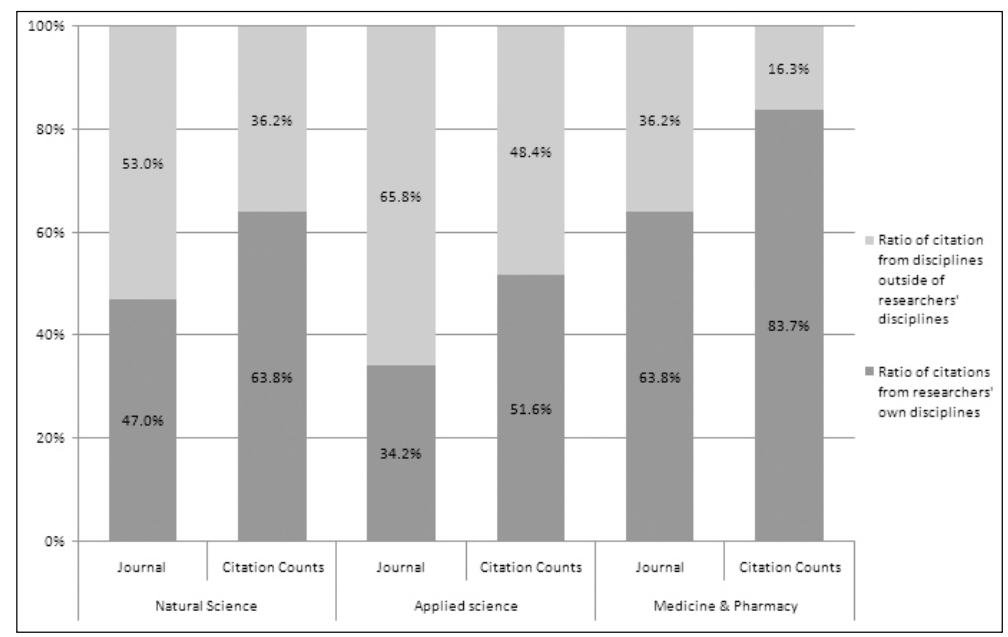

〈Figure 3〉 The Ratio of Citations from Researchers' Own Disciplines to Citation from Disciplines Outside of Researchers' Disciplines 
124 Journal of the Korean Society for Information Management, 28(2), 2011

\subsection{Language and country of cited journals}

As illustrated in $<$ Figure $4>$ below, the top ten most frequently used languages in cited journals were identified. Most cited foreign journals were written in English. 2\% of cited foreign journals was written in other than top ten languages, and they accounted for $0.1 \%$ of total citation counts.
Countries of publishers for cited foreign journals were identified in $<$ Figure 5 $>$. Overall, there was a positive relationship between the number of cited journals and countries' citation counts. However, Germany and Japan had relatively low citation counts compared to their share rates of cited journals. And $9.3 \%$ of journals had been published by other than top twenty countries, and they accounted for $0.8 \%$ of total citation counts.

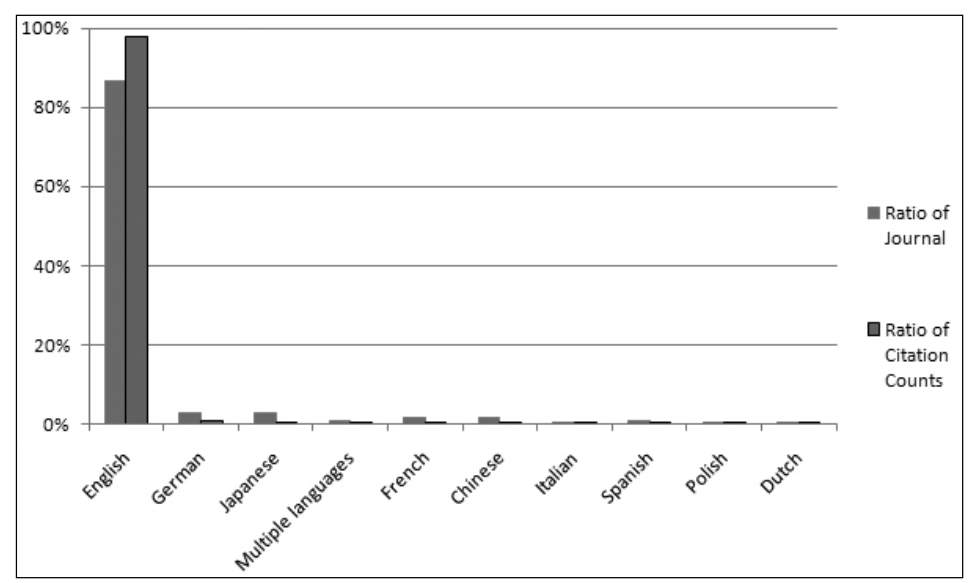

〈Figure 4〉 Ratio for Languages of Cited Journals

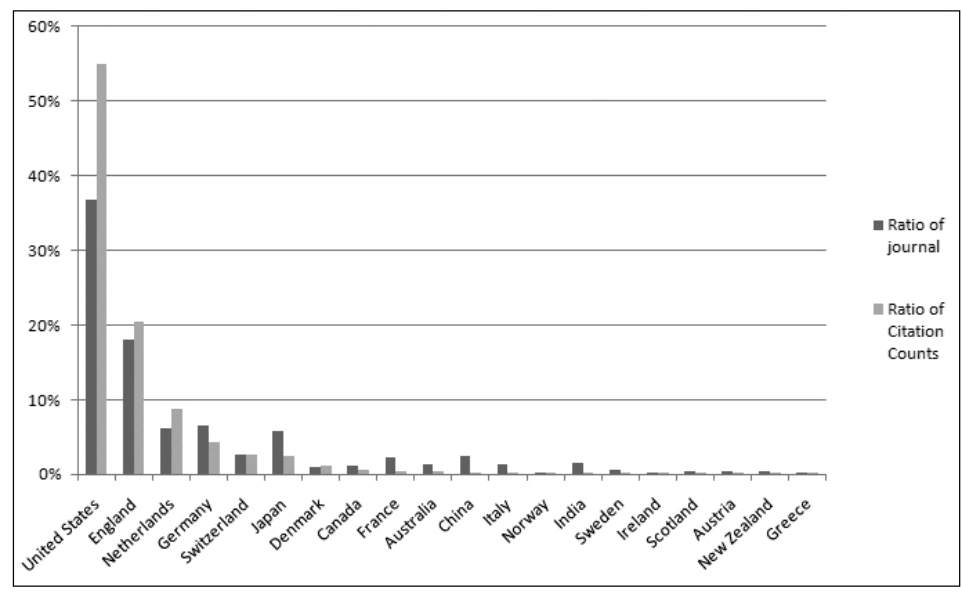

$\langle$ Figure 5〉 Countries for Publishers of Cited Journals 


\subsection{Immediacy, peak time and half- life of cited foreign documents}

The age (=year) of cited document indicates the elapsed time since that document was published. In other words, the age of cited document can be analyzed to determine the time required for a document to become cited once it has been published. In this re- search, citation ages (i.e., immediacy, peak-time, and half-time of citation) were analyzed as illustrated in $<$ Table $4>$. The immediacy rate of citation measures the percentage of citing documents published in a given year, and the peak time of citation refers to the most frequently cited year. Also, citation half-life, which calculates the life cycle of documents, indicates the year that accounts for $50 \%$ of current citation counts.

〈Table 4〉 Analysis of Citation Ages for Cited Foreign Journals

\begin{tabular}{|c|c|c|c|c|}
\hline $\begin{array}{c}\text { Broad } \\
\text { Classification }\end{array}$ & Narrow Classification & $\begin{array}{c}\text { Immediacy } \\
\text { Citation Ratio }\end{array}$ & Half-life & Peak-time \\
\hline \multirow{8}{*}{ Natural Science } & Mathematics & $0.68 \%$ & 10.3 & 5 \\
\hline & Astronomy & $2.12 \%$ & 9.0 & 2 \\
\hline & \begin{tabular}{|l|} 
Physics \\
\end{tabular} & $0.92 \%$ & 7.0 & 3 \\
\hline & \begin{tabular}{|l|} 
Chemistry \\
\end{tabular} & $1.88 \%$ & 8.0 & 2 \\
\hline & Ethnography,Geology & $1.38 \%$ & 11.3 & 5 \\
\hline & Life Science & $1.74 \%$ & 8.0 & 4 \\
\hline & Plant & $1.26 \%$ & 9.7 & 5 \\
\hline & Animals & $0.87 \%$ & 11.3 & 5 \\
\hline & Average (Natural Science) & $1.36 \%$ & 9.3 & 3.9 \\
\hline \multirow{10}{*}{ Applied Science } & Computer Information & $1.84 \%$ & 6.7 & 3 \\
\hline & General Engineering & $2.96 \%$ & 7.7 & 2 \\
\hline & General Engineering & $1.83 \%$ & 8.0 & 3 \\
\hline & Applied Physics & $1.61 \%$ & 7.3 & 3 \\
\hline & Construction, Architecture and Civil Engineering & $1.16 \%$ & 10.0 & 5 \\
\hline & Urban and Environment & $2.30 \%$ & 8.7 & 3 \\
\hline & Agriculture & $1.21 \%$ & 11.3 & 6 \\
\hline & Home Economics & $0.84 \%$ & 11.0 & 8 \\
\hline & Chemical Engineering & $1.43 \%$ & 8.0 & 3 \\
\hline & Manufacturing & $1.70 \%$ & 8.7 & 5 \\
\hline & Average (Applied Science) & $1.62 \%$ & 8.8 & 4.1 \\
\hline \multirow{7}{*}{$\begin{array}{l}\text { Medicine \& } \\
\text { Pharmacy }\end{array}$} & General Medicine & $1.27 \%$ & 8.0 & 3 \\
\hline & Basic Medical & $0.99 \%$ & 9.3 & 5 \\
\hline & Social Medicine & $1.19 \%$ & 9.0 & 3 \\
\hline & Pharmacology \& Therapeutics & $1.91 \%$ & 8.0 & 4 \\
\hline & Internal Medicine & $1.60 \%$ & 7.7 & 2 \\
\hline & \begin{tabular}{|l|} 
Surgery \\
\end{tabular} & $0.74 \%$ & 10.0 & 5 \\
\hline & Obstetrics and Gynecology & $1.60 \%$ & 9.3 & 4 \\
\hline \multirow{2}{*}{\multicolumn{2}{|c|}{$\frac{\text { Average (Medicine \& Pharmacy) }}{\text { Average (Total) }}$}} & $1.33 \%$ & 8.8 & 3.7 \\
\hline & & $1.46 \%$ & 9.0 & 3.9 \\
\hline
\end{tabular}


126 Journal of the Korean Society for Information Management, 28(2), 2011

The analysis of citation age is an effort to measure the changing speed of knowledge. In particular, knowing the speed of knowledge transfer and degradation plays a critical role in understanding modern knowledge-based society. It helps in understanding characteristics of academic disciplines and managing information effectively, in addition to evaluating researchers or journals. For instance, a journal article citing recent documents is not always rated high because the tempos of knowledge transfer and degradation are significantly different depending on nature of disciplines. However, the fact is that knowledge is going to be degraded from the peak-time of citation. That is, reaching the half-life of citation means that the lifetime of document is halved, so that the value of specific document being analyzed is decreasing. (lee 1996).
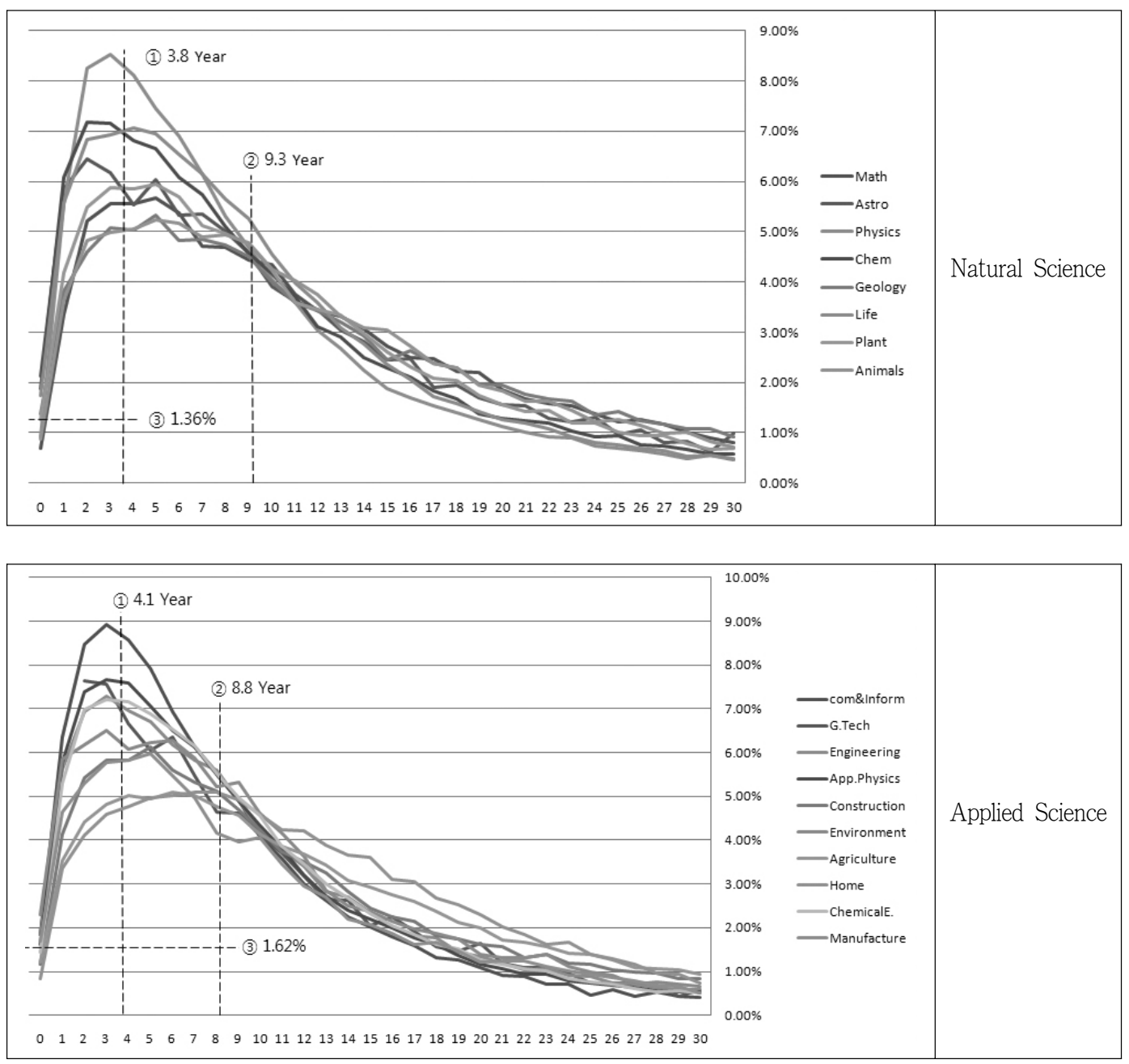


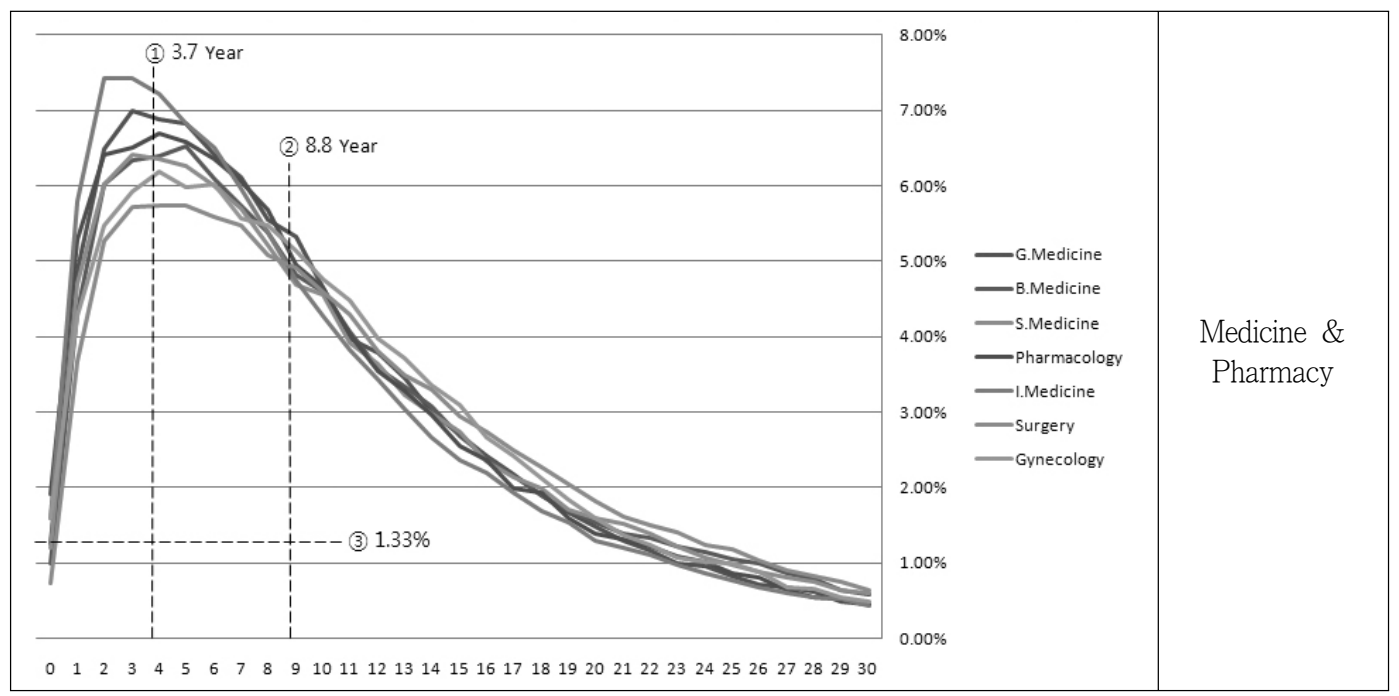

$\langle$ Figure $6,7,8\rangle$ Citation Age by Field (Immediacy Index, Peak-time, Half-life)

$<$ Figure 6,7 and $8>$ are graphs of $<$ Table $4>$. From these figures, it was possible to compare the trends of citation ages according to various disciplines. When it comes the rate of citation immediacy, the average rate was $1.46 \%$. The immediacy citation rate was lowest in medicine \& pharmacy (3.7\%) rather than natural science (3.8\%) and applied science (4.1\%). With respect to the peak time of citation, the average year was 3.9 years, and medicine \& pharmacy had the fastest peak time, followed by natural science and medicine \& pharmacy. For the half-life of citation, medicine $\&$ pharmacy had the same peak time with applied science ( 8.8 years) while the half-life of citation in natural science was 9.3 years. The average half-life of citation was 9 years. From this result, it turned out that documents published in a given year were not cited frequently because of limitation in distribution. Also, the result showed that Korean scientists prefer to cite docu- ments recently (e.g. those that are 4 to 10 years old). Although mentioned in previous studies, this research has a value in that it produced reliable numeric indicators for citation data by analyzing journal articles published between 2005 and 2009 from every field of science and technology. In addition, compared to research analyzing citing behavior of Korean scientists on domestic journals, the peak time and half-life of foreign journals were longer (about 2 times) than those of domestic journals but immediacy citation ratio for foreign journals was $60 \%$ smaller than that of domestic journals.

\subsection{Analysis of foreign journal publishers and the listing of global citation index service}

The share ratio of the number of cited foreign journals and citation counts for them were illustrated 
128 Journal of the Korean Society for Information Management, 28(2), 2011

in $<$ Figure $9,10>$. The only top ten publishers were described based on their share ratio. It was found that share ratio of publishers could be changed depending on the number of journals or citation counts. From this analysis, popular publishers could be iden- tified in future research.

The effect of whether or not foreign journals were covered in SCI(E) or SCOPUS on citation count was analyzed. ( $<$ Table $5>$, $<$ Figure $11>$ ). $21 \%$ of cited foreign journals was not covered in SCI(E)
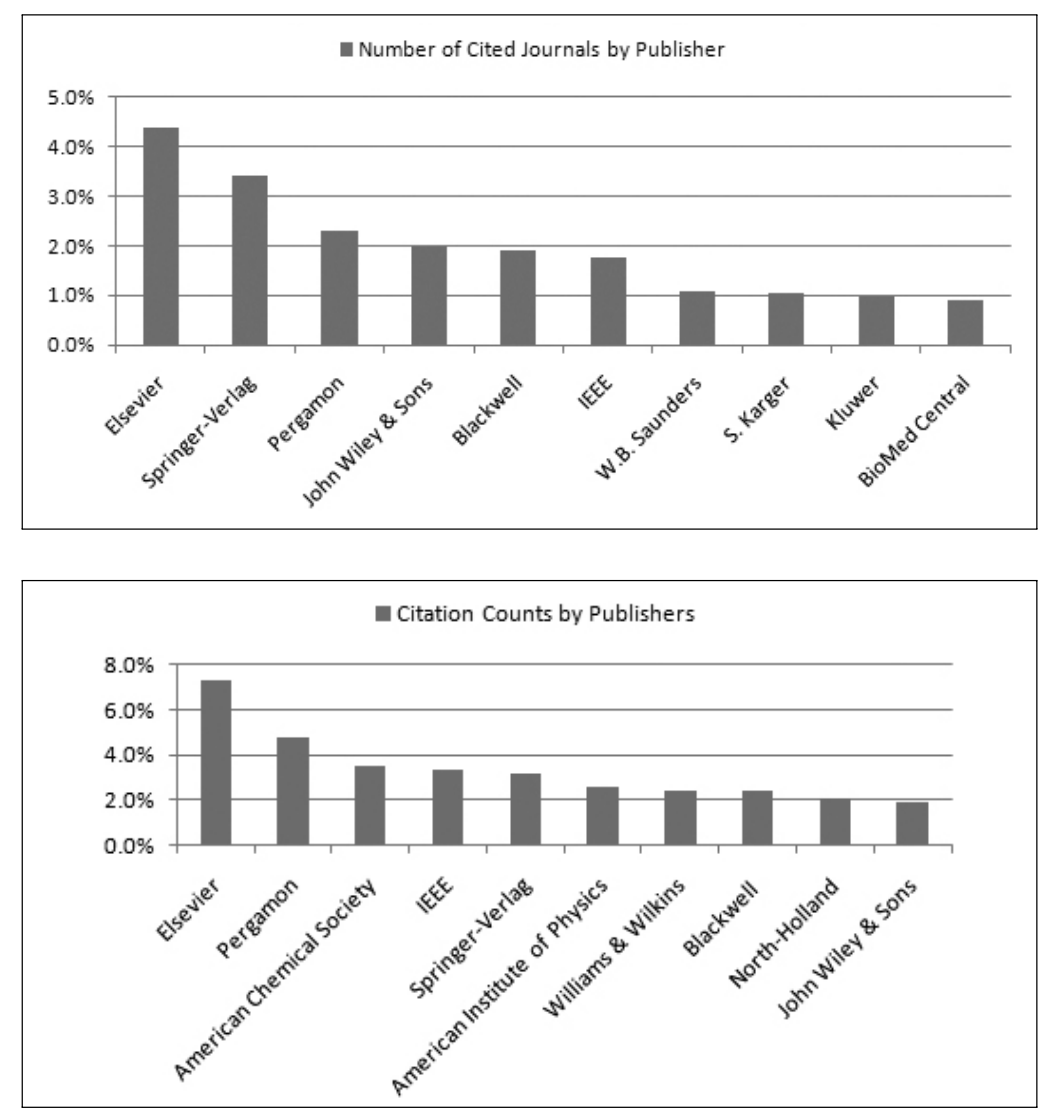

〈Figure 9, 10〉 Share Ratio of Top Ten Publishers

〈Table 5〉 Comparison of Citation Counts Between SCI(E) or SCOPUS Listed and Unlisted Journals

\begin{tabular}{c|c|c|r|r|r}
\hline \multicolumn{7}{|c}{ Average citation counts for listed and unlisted journals } \\
\hline Category & $\begin{array}{c}\text { Number of } \\
\text { Journal }\end{array}$ & $\begin{array}{c}\text { Number of } \\
\text { Journal }(\%)\end{array}$ & $\begin{array}{c}\text { Citation } \\
\text { Count }\end{array}$ & $\begin{array}{c}\text { Citation } \\
\text { Count }(\%)\end{array}$ & $\begin{array}{c}\text { Average } \\
\text { Citation Count }\end{array}$ \\
\hline Listed & 11,529 & $78.67 \%$ & $1,839,878$ & $98.06 \%$ & 159.59 \\
\hline Unlisted & 3,125 & $21.33 \%$ & 36,495 & $1.94 \%$ & 11.68 \\
\hline Total & 14,654 & $100.00 \%$ & $1,876,373$ & $100.00 \%$ & 128.05 \\
\hline
\end{tabular}


or SCOPUS, and their citation counts only accounted for about $2 \%$ of total citation count. And about $41 \%$ of journals were listed on both SCI(E) and SCOPUS, and their citation counts accounted for about $89 \%$ of total citation counts. This result indicates that Korean researchers prefer to cite foreign journals that are covered in $S C I(E)$ or SCOPUS rather than journals that are not covered.

\subsection{Analysis for subscription to electronic foreign journals in Korea}

As implied in 3.5 above, providing information for frequently used foreign journals is important. There are two ways of subscribing to foreign journals, which are DDS service that relies on subscribing to paper journals and licensing electronic journals via on-line, and the latter has been increasing in recent years. In this research, as stated in introduction, e-Gate Knowledge Base of the Korean Electronic Site License Initiative (KESLI) was used for investigating current situation of subscription to cited foreign journals because e-Gate KB has licensing information for electronic journals in Korean institutions. The result of analyzing situations for subscription to foreign journals was shown in $<$ Figure $11>$. From this graph, it was found that foreign electronic journals that are listed on SCI(E) or SCOPUS and licensed by institutions accounted for $90 \%$ of total citation counts. This could mean that frequently cited foreign journals have been already subscribed electronically by institutions. However, some foreign journals that were listed on SCI(E) or SCOPUS have not been licensed by institutions in Korea even though they accounted for $10 \%$ of total citation counts.

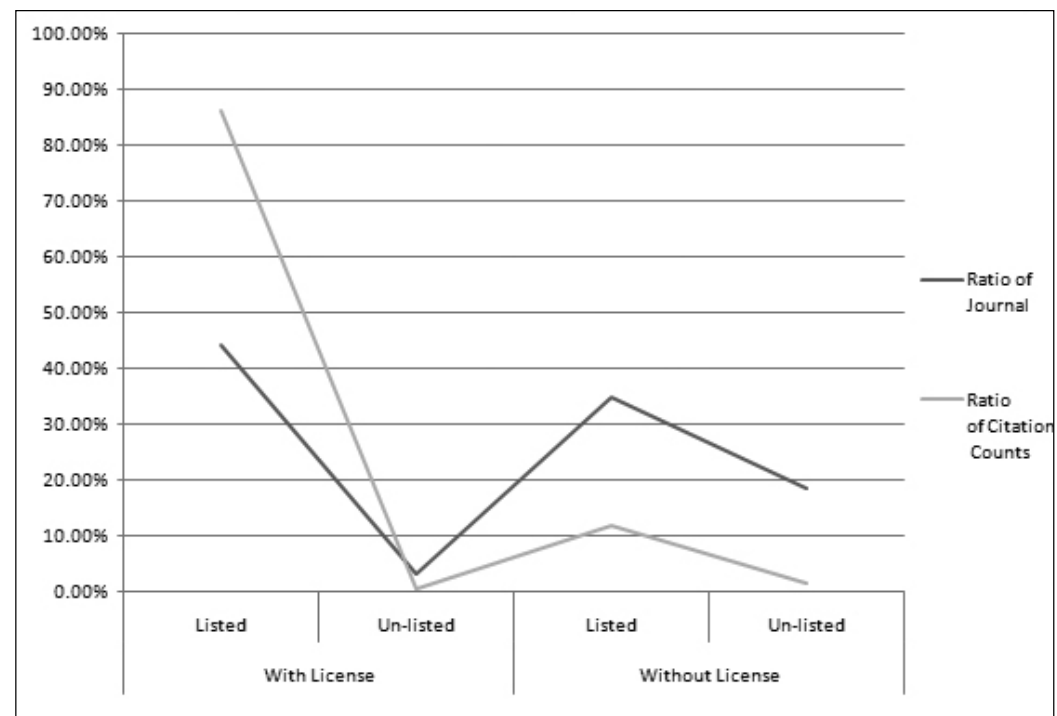

〈Figure 11〉 Current Situation for Subscribing to Electronic Foreign Journals 
130 Journal of the Korean Society for Information Management, 28(2), 2011

Foreign journals that were covered in $\operatorname{SCI}(E)$ or SCOPUS but were not subscribed by institutions in Korea were analyzed in $<$ Table $6>$ with citation counts.
Of these journals, highly cited electronic journals were selected in $<$ Table $7>$ and arranged in order of priority for licensing.

〈Table 6〉SCI(E) or SCOPUS Listed Journals Without Licensing

\begin{tabular}{c|c|r|r|r|r}
\hline \multicolumn{7}{c}{ Listed journals without licensing } \\
\hline \multirow{4}{*}{$\begin{array}{c}\text { Outstanding } \\
\text { Journal }\end{array}$} & Citation Count & Number of Journal & Ratio of Journal & Citation Count & Citation Rate \\
\cline { 2 - 6 } & Over 160 & 266 & $5.23 \%$ & 140,340 & $63.16 \%$ \\
\cline { 2 - 6 } & $130 \sim 160$ & 65 & $1.28 \%$ & 9,323 & $4.20 \%$ \\
\cline { 2 - 6 } & $100 \sim 130$ & 84 & $1.65 \%$ & 9,550 & $4.30 \%$ \\
\cline { 2 - 6 } & Under 100 & 4,668 & $91.84 \%$ & 62,992 & $28.35 \%$ \\
\cline { 2 - 6 } & Total & 5,083 & $100.00 \%$ & 222,205 & $100.00 \%$ \\
\hline
\end{tabular}

〈Table 7〉 Highly Cited Electronic Journals Without Licensing in Korea

\begin{tabular}{|c|c|c|c|c|c|}
\hline Section & Journal Title & ISSN & Country & Language & $\begin{array}{c}\text { Citation } \\
\text { Count }\end{array}$ \\
\hline \multirow{9}{*}{$\begin{array}{l}\text { SCI }(\mathrm{E}) \text { or } \\
\text { SCOPUS-listed } \\
\text { Journals } \\
\text { (Above the } \\
\text { average) }\end{array}$} & Hepatology & 0161-0538 & U.S.A & English & 793 \\
\hline & 自然 $=$ Nature & 0387-0014 & Japan & Japanese & 667 \\
\hline & The journal of physical chemistry & $0092-7325$ & U.S.A & English & 273 \\
\hline & $\begin{array}{l}\text { 材料の科學と工學 = Materials science and } \\
\text { technology }\end{array}$ & $1347-4774$ & Japan & Japanese & 246 \\
\hline & Journal of polymer science & 0022-3832 & U.S.A & English & 230 \\
\hline & Die Makromolekulare Chemie & 0025-116x & Germany & English & 188 \\
\hline & $\begin{array}{l}\text { 日本食品工業學會誌 = Journal of food science } \\
\text { and technology }\end{array}$ & 0029-0394 & Japan & Japanese & 175 \\
\hline & PESC record & 0275-9306 & U.S.A & English & 173 \\
\hline & 人類工效學 $=$ Ergonomics & $1006-8309$ & China & Chinese & 169 \\
\hline \multirow{8}{*}{$\begin{array}{c}\text { Total Journals } \\
\text { (Above the } \\
\text { average) }\end{array}$} & 這空 $=$ Vacuum & 1002-0322 & China & Chinese & 156 \\
\hline & Operating systems review & 0163-5980 & U.S.A & English & 139 \\
\hline & Archives of surgery & $0272-5533$ & U.S.A & English & 138 \\
\hline & Journal of applied physiology & 0021-8987 & U.S.A & English & 134 \\
\hline & Materials Research Society symposia proceedings & 0272-9172 & U.S.A & English & 134 \\
\hline & Home economics research journal & 0046-7774 & U.S.A & English & 133 \\
\hline & Recent developments in carbohydrate research & & India & English & 131 \\
\hline & $\begin{array}{l}\text { Anesth\&eacute; sie, analg\&eacute; sie, } \\
\text { r\&eacute; animation }\end{array}$ & $0003-3014$ & France & French & 130 \\
\hline
\end{tabular}




\begin{tabular}{|c|c|c|c|c|c|}
\hline Section & Journal Title & ISSN & Country & Language & $\begin{array}{c}\text { Citation } \\
\text { Count }\end{array}$ \\
\hline \multirow{11}{*}{$\begin{array}{l}\text { Cited by more } \\
\text { than } 100 \text { times }\end{array}$} & Transfusion & 0372-1248 & France & French & 127 \\
\hline & Combined cumulative index to cardiology & 0747-5330 & U.S.A & English & 127 \\
\hline & Gann & 0016-450x & Japan & $\begin{array}{c}\text { Multiple } \\
\text { languages }\end{array}$ & 125 \\
\hline & Chemical communications & 0366-5607 & Sweden & English & 123 \\
\hline & The Journal of fuzzy mathematics & $1066-8950$ & U.S.A & English & 122 \\
\hline & Chemistry reviews & 1071-6114 & Switzerland & English & 119 \\
\hline & ASCE & 0730-3149 & U.S.A & English & 115 \\
\hline & $\begin{array}{l}\text { SID International Symposium Digest of Technical } \\
\text { Papers }\end{array}$ & $0003-966 x$ & U.S.A & English & 113 \\
\hline & $\begin{array}{l}\text { Journal of the American Pharmaceutical } \\
\text { Association }\end{array}$ & $0095-9553$ & U.S.A & English & 108 \\
\hline & Trends in biochemical sciences. Reference edition & 0376-5067 & Netherlands & English & 105 \\
\hline & The journal of immunology & 1048-3233 & U.S.A & English & 103 \\
\hline
\end{tabular}

\section{Conclusion}

To understand citing behavior of Korean scientists on foreign journals, this paper analyzed cited references from 2005 to 2009 available from KSCD in addition to e-Gate Knowledge Base. That is, around 15,000 foreign journals that were identified by citation analysis and mapping with e-gate $\mathrm{KB}$ were analyzed. The following is a summary of the results of this research. First, the ratio of foreign documents cited by articles of science and technology in Korea was $75.35 \%$, and $78 \%$ of cited foreign documents was journal article. Second, the results showed that foreign journals were the most highly cited in medicine $\&$ pharmacy, followed by applied science and natural science. It also showed that medicine \& pharmacy had the highest citation count, followed by natural science and applied science. And the ratio of citation from disciplines outside of researchers' disciplines was the highest in applied science, natural science and pharmacy \& medicine in that order. Third, cited foreign journals were mostly written in English. $2 \%$ of cited foreign journals was written in other than top ten most frequently used languages, and they accounted for $0.1 \%$ of total citations. For the countries of publications, most publications were written in the United States and the United Kingdom, and $9.3 \%$ of journals was written in other than top twenty countries (93 countries). Citation counts from 93 countries accounted for $0.8 \%$ of total citation, and Germay, Japan, France, China, and India had relatively low citation counts compared with their number of journals. Forth, citation ages for cited foreign journals were identified. That is, the immediacy citation rate (average 1.46\%), peak-time (average 3.9 years), and half-life (average 9 years) of cited 
foreign journals were found. Compared to research analyzing citing behavior of Korean scientists on domestic journals, the peak time and half-life of foreign journals were longer (about 2 times) than those of domestic journals but immediacy citation ratio for foreign journals was $60 \%$ smaller than that of domestic journals. Fifth, foreign journals listed on $S C I(E)$ or SCOPUS were highly cited compared to journals not listed. About $41 \%$ of cited foreign journals were listed on both $S C I(E)$ and SCOPUS, and they accounted for about $89 \%$ of total citation count. Finally, this study found that foreign electronic journals that are listed on SCI(E) or SCOPUS and licensed by institutions accounted for $90 \%$ of total citation counts. And some foreign journals that are listed on $\operatorname{SCI}(E)$ or SCOPUS have not been licensed by institutions in Korea even though they accounted for $10 \%$ of total citation counts.

From this research, we could understand citing behavior of Korean scientists on foreign journals for their domestic publications and acquire reliable statistical information. The results of this research will be useful for establishing strategies for licensing foreign electronic journals and for information services. In the future research, the scope of research will be broken down by various citing behavior, and the coverage of KSCD is going to be widened by linking to supplementary databases for a more accurate and reliable analysis.

\section{References}

Bonzi, Susan and H. W. Snyder. 1991. "Motivations for citation: A comparison of self citation and citation to others." Scientometrics, 21(2): 245254.

Cho, Hyun-Yang. 2010. “A comparative study on researchers' language preference for citing documents in different subject fields." Journal of the Korean BIBLIA Society for Library and Information Science, 21(1): 212- 221.

Cho, Hyun-Yang and Hyun-Sun Cho. 2005. “A comparative study on the citing behavior of scholars in four major engineering fields." Journal of Information Management, 36(2): 1-24.
Friss, Th. 1955. "The Use of cita-tion-analysis as a research technique and its impli-cations for libraries." South African Libraries, 23: 12-15.

Gross, P. L. K., and E. M. Gross. 1927. "College libraries and chemical education." Science, 66: 385-389.

Han, Jong-Yup. 2005. "An scholastic analysis on the SCI publication results and research capability of major academic and research institute in oceanography." Journal of Korean Library and Information Science Society, 36(4): 309328.

Kim, Hong-Ryul. 2003. "A study on the citation 
analysis of the information Resources on Science \& Technology." Journal of the Korean Society for Information Management, 20(4): $1-21$.

kim, Kapseon. 2002. "The Co-occurrence phenomenon of both Korean and Non-Korean literatures within the Korean references: An analysis on the citation motivations and references by social scientisis." Journal of KLISS, 36(4): 21-47.

Ko, Seong-Soon and Sang-Ki Choi. 2005. "Analysis on the foreigan journals seeking behaviours through citation analysis.” Journal of Korean Library and Information Science Society, 13(2): 121-142.

Lee, K. J. Public Administration Review, 30(2) 97-112.

Lee, Seung-Won. 2008. "A study on the information use behaviors through citation analysis." Journal of Information Management, 39(2):
185-209.

Yu, So-Young and Jae-Yun Lee. 2008. "Journal citation analysis for library services on interdisciplinary domains: A case study of departmaet of biotechnology, Y University." Journal of the Korean Society for Information Management, 25(4): 284-308.

KSCD (Korea Science Citation index Database). [cited 2011.5]. <http://ksci.kisti.re.kr>.

NDSL. [cited 2011.5]. <http://www.ndsl.kr>.

KSCI (Korea Science Citation Index). [cited 2011.5]. $<\mathrm{http}$ //ksci.kisti.re.kr>.

Korea Society Community of Science and Technology. [cited 2011.5]. <http://society.kisti.re.kr>.

KoreaScience. [cited 2011.5].

$<\mathrm{http} / / /$ www.koreascience.or.kr>

KESLI (Korean Electronic Site License Initiative). [cited 2011.5]. <www.kesli.or.kr>. 